\title{
Herodias and Salome in Mark's story about the beheading of John the Baptist
}

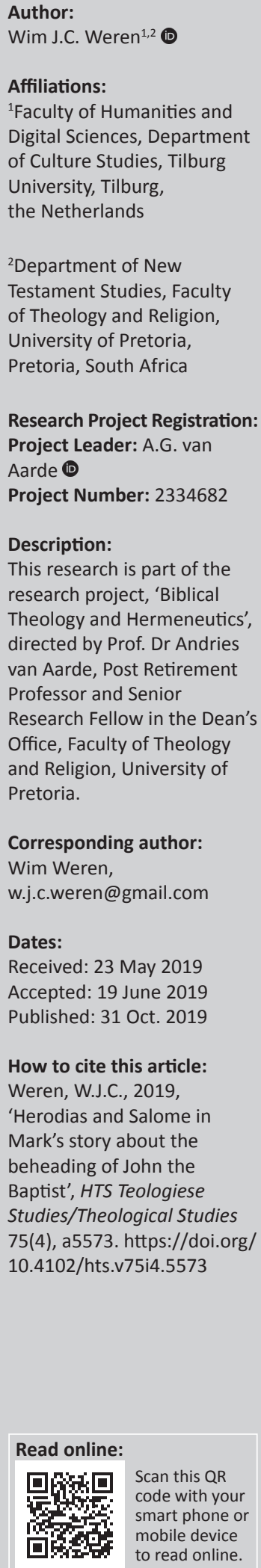

According to Mark 6:14-29, John the Baptist was beheaded by the order of Herod Antipas. This dramatic event became inevitable after a cunning interplay between Herodias and her daughter, who remains nameless in the New Testament. According to Flavius Josephus, she was called Salome (Jewish Antiquities XVIII, $5.4 \S 136-137)$, and under that name, she went down in history. For the sake of convenience, I also call her 'Salome' in this article. Salome is the Greek form of the Hebrew name Shlomith, which was very popular in early Judaic times and means 'she who brings peace and tranquillity'. Unlike the faithful women elsewhere in Mark's gospel (5:21-43; 7:24-30; 14:3-9), Herodias and her daughter are not exactly models of virtue. Yet, it is questionable as to whether they are both thoroughly bad and whether they are both equally responsible for the murder of John. This article does not provide a historical reconstruction of what exactly happened at the court of Herod Antipas, but it contains a narrative analysis of what happened in the court of Herod Antipas. This narrative analysis is followed by an intertextual approach in the second part of this article. Firstly, I will compare Mark's story with what Flavius Josephus tells about the beheading of John. Thereafter, I will highlight the roles of Herodias and Salome in the play Salome by Oscar Wilde from 1894, which, in turn, forms the basis of the libretto for the opera Salome by Richard Strauss from 1905. Do we encounter in these modern artistic recreations (Neuschöpfungen) only transformations of Mark's story, or also transgressions in which Wilde and Strauss have largely replaced the original meaning of the story with new meaning?

Keywords: Mark 6:14-29; Herodias; Salome; John the Baptist; Flavius Josephus; Oscar Wilde; Richard Strauss; literary analysis; intertextuality.

\section{The story of Mark}

In the Holy Bible New Revised Standard Version, the story of Mark 6:14-29 reads as follows: ${ }^{1}$

$6{ }^{14} \mathrm{King}$ Herod heard of it, for Jesus' name had become known. Some were saying, 'John the baptizer has been raised from the dead; and for this reason these powers are at work in him'. ${ }^{15}$ But others said, 'It is Elijah'. And others said, 'It is a prophet, like one of the prophets of old' ${ }^{16}$ But when Herod heard of it, he said, 'John, whom I beheaded, has been raised'. ${ }^{17}$ For Herod himself had sent men who arrested John, bound him, and put him in prison on account of Herodias, his brother Philip's wife, because Herod had married her. ${ }^{18}$ For John had been telling Herod, 'It is not lawful for you to have your brother's wife'. ${ }^{19}$ And Herodias had a grudge against him, and wanted to kill him. But she could not, ${ }^{20}$ for Herod feared John, knowing that he was a righteous and holy man, and he protected him. When he heard him, he was greatly perplexed; and yet he liked to listen to him..$^{21}$ But an opportunity came when Herod on his birthday gave a banquet for his courtiers and officers and for the leaders of Galilee. ${ }^{22}$ When his daughter Herodias [other translations: The daughter of Herodias] came in and danced, she pleased Herod and his guests; and the king said to the girl, 'Ask me for whatever you wish, and I will give it'. ${ }^{23}$ And he solemnly swore to her, 'Whatever you ask me, I will give you, even half of my kingdom'. ${ }^{24}$ She went out and said to her mother, 'What should I ask for?' She replied, 'The head of John the baptizer'. ${ }^{25}$ Immediately she rushed back to the king and requested, 'I want you to give me at once the head of John the Baptist on a platter' ${ }^{26}$ The king was deeply grieved; yet out of regard for his oaths and for the guests, he did not want to refuse her. ${ }^{27}$ Immediately, the king sent a soldier of the guard with orders to bring John's head. He went and beheaded him in the prison, ${ }^{28}$ brought his head on a platter, and gave it to the girl. Then the girl gave it to her mother. ${ }^{29}$ When his disciples heard about it, they came and took his body, and laid it in a tomb.

\section{Who is who?}

In this story, many characters belong to the Herodian family. The question is who is who and what are their mutual relationships? Therefore, I will first present a number of personal details.

1.This article is an adaptation and extension and English translation of Chapter 10 of my recently published book written in Dutch (Weren 2018 ).

Copyright: (C) 2019. The Authors. Licensee: AOSIS. This work is licensed under the Creative Commons Attribution License. Note: HTS 75th Anniversary Maake Masango Dedication. 


\section{Antipas}

At the beginning of his story, Mark speaks about 'king Herod' and further on he calls him four times 'the king' $(6: 22,25,26,27)$. This is confusing for two reasons. The first reason is that within the Herodian family, there are several persons named Herod. In the New Testament, there are three of them: Herod the Great, Herod Antipas and Herod Agrippa. In Mark 6:14-29, Herod Antipas is meant. He is a son of Herod the Great, who is best known in the New Testament for the infanticide in Bethlehem (Mt 2). The Roman senate had authorised Herod the Great to carry the title of king. After his death in $4 \mathrm{BC}$, the area over which he ruled was divided among three of his sons: Archelaus (Judea and Samaria), Antipas (Galilee and Perea) and Philip (Iturea and Trachonitis).

That Mark calls Antipas 'king' is, historically speaking, not correct. From 4 BC until 37 AD, Antipas ruled Galilee and Perea, but he was not a king but a tetrarch. In 37 AD, Emperor Gaius Caligula removed Antipas from his position as a tetrarch and banished him to Gaul because Antipas had tried to qualify for the title of king through intrigues.

\section{Herodias}

In Mark 6:14-29, Herodias plays an important role. The name 'Herodias' is the feminine form of the masculine name Herod, which means 'hero'. She was the granddaughter of Herod the Great and a daughter of Aristobulus and Bernice. According to Mark 6:17, Herodias had previously been the wife of Antipas' half-brother Philip ('Herodias, his brother Philip's wife'). This Philip can hardly be anyone else but Philip the tetrarch, who is indeed a half-brother of Antipas and who ruled Iturea and Trachonitis from 4 BC until his death in 34 AD. However, according to Josephus' Jewish Antiquities (XVIII, $5.1 \S 109,5.4 \S$ 136), Herodias was married to Herod. He was a son of Herod the Great and Mariamne, the daughter of Simon the high priest. This couple had a daughter named Salome.

Therefore, Mark and Josephus contradict each other. Many exegetes have tried to smooth out this difference by combining the Herod of Josephus and the Philip of Mark into a new person, named Herod Philip.

This is a form of conflation. The problem is, however, that 'there is no single source attesting to a person by this name' (i.e. the name Herod Philip; see The Anchor Bible Dictionary, Volume 3, 160). Meier (1994:172) even claims that 'Herod Philip never existed outside the minds of conservative exegetes'. In my opinion, we can best settle this discussion by referring to the first husband of Herodias as 'Herod', without providing this name with a further addition.

Herodias left her first husband to enter into a relationship with her uncle Herod Antipas, the tetrarch. For the marriage of Herodias and Antipas to take place, two divorces were needed: Herodias herself left her first husband, and Antipas broke his marriage with a Nabataean princess, the daughter of King Aretas IV.

\section{Herodias' daughter}

In Mark 6:22a, a young girl appears on the scene. It is precisely in this verse that we encounter a complicated text-critical problem. In essence, there are two different readings:

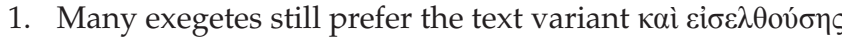

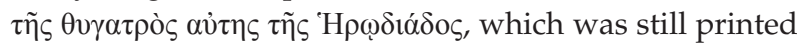
in the 25th edition of Nestle-Aland (1963). This variant with $\alpha \dot{v} \tau \eta \varsigma \tau \tilde{\eta} \varsigma$ occurs in the majority of manuscripts. In this case, the young girl is the daughter of Herodias herself' or 'the daughter of the said Herodias' from her first marriage, and Antipas is the stepfather of that girl (see also Kraemer 2006:321-349; Streete 2018:17).

2. In some authoritative manuscripts, such as Sinaiticus, Vaticanus and Codex Bezae, the text reads as follows: $\kappa \alpha i$

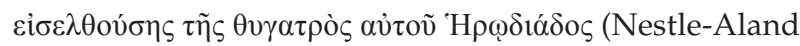
1979:107). This reading is printed in Nestle-Aland since the 26th edition. The word aviov is striking here. The Holy Bible New Revised Standard Version (1989:41) prefers this reading and translates this verse as follows: 'When his daughter Herodias came in'. This choice implies that the young girl is the daughter of Herod Antipas himself, and that her name is Herodias, just like her mother,

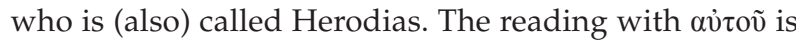
the lectio difficilior and 'must be adopted on the strength of its external attestation' (Metzger 1975:90). Because according to Mark 6:24,28, Herodias is the mother of this girl, this girl must be the daughter of Antipas and Herodias. Antipas is not her paternal uncle but her father.

From the point of view of textual criticism, we prefer reading point (2). Nevertheless, some reluctance is appropriate for two reasons. The first reason is that this reading differs from Josephus' claim that Salome is the daughter of Herodias and her first husband. Or, should we assume that the daughter in Mark's story has only been identified with the Salome from Josephus' story in subsequent traditions (so another form of conflation)? The second reason is that it is remarkable that when we prefer reading point (2), both mother and daughter are called Herodias. This is, of course, possible, but it is a fact that most later exegetical and artistic interpretations of Mark's story are based on the family relationships described by Josephus, and there she is called Salome.

In Mark's story, Herodias' daughter is probably still a teenager. According to some historians, she was born around $10 \mathrm{AD}$ or $14 \mathrm{AD}$. At a young age, she married her paternal uncle Philip, who, until his death in $34 \mathrm{AD}$, was the tetrarch of Iturea and Trachonitis. After his death, she married her cousin Aristobulus of Armenia Minor, the son of Herod of Chalcis, who was a brother of her mother Herodias (Jewish Antiquities XVIII, 5.4 § 136-137).

The relationships outlined here become clearer when we present some parts of the Herodian family tree, starting with Herod the Great and four of the 10 wives to whom he was 


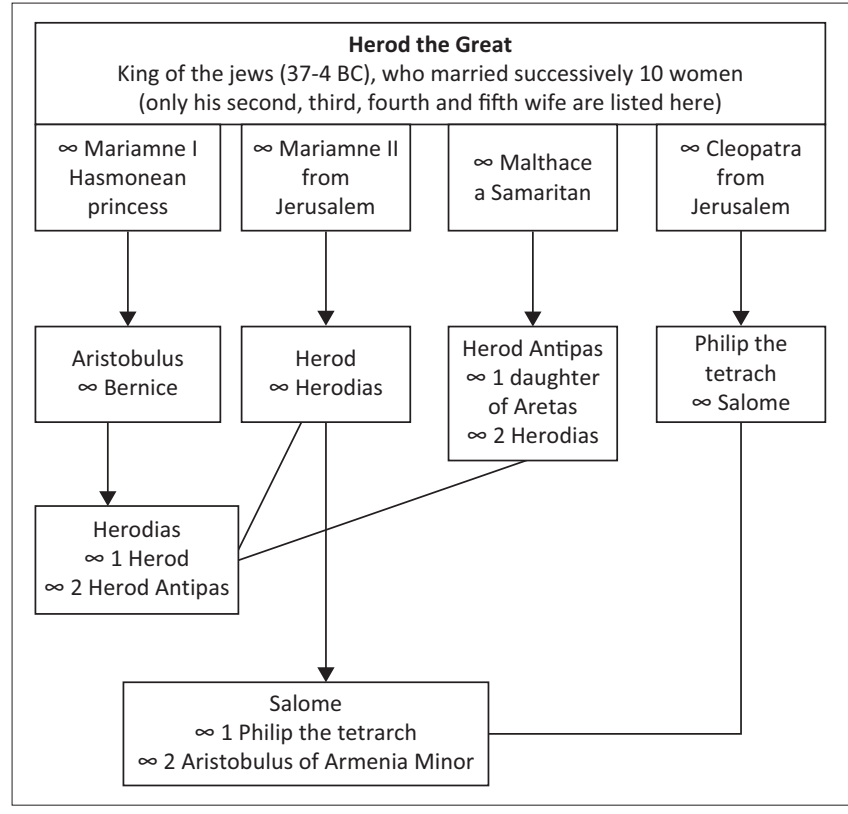

FIGURE 1: Herodian family tree.

married $(\infty=$ married to; uninterrupted line $=$ marriage relationship) ${ }^{2}$ (see Figure 1).

\section{Narrative analysis of Mark 6:14-29 Structure}

The story about the beheading of John (B) is framed by another story (A), which is split into two (A1 and A2), so that A2 is the continuation of A1. In exegetical circles, this literary technique is known as a sandwich construction. The central story B and the surrounding story (A) illuminate each other. This pattern regularly occurs in the Gospel of Mark. In the case of Mark 6:14-29, this literary construction looks as follows:
A1 6:7-13
Jesus sends the Twelve out and lets them share in his own work
B 6:14-29 Intermezzo: the end of life of John the Baptist
A2 6:30-31 Return of the apostles after their successful tour.

Story B causes a certain delay here and fills the gap in time between the departure and the return of the Twelve. Even more exciting is that it appears that the work of the Twelve is risky, just as John's work was. The central story B about the end of John's life has a solid structure that looks like:

\begin{tabular}{|c|c|c|c|c|}
\hline A & 6:14-16 & \multicolumn{3}{|c|}{$\begin{array}{l}\text { Rumours about the identity of Jesus and the } \\
\text { opinion of Herod }\end{array}$} \\
\hline B & $6: 17-20$ & \multicolumn{3}{|c|}{$\begin{array}{l}\text { John's criticism of the relationship of Antipas } \\
\text { with Herodias }\end{array}$} \\
\hline C & $6: 21-29$ & \multicolumn{3}{|c|}{ Murder of John } \\
\hline & & $\mathrm{C} 1$ & $6: 21-23$ & $\begin{array}{l}\text { Salome's dance and the } \\
\text { oath of Herod }\end{array}$ \\
\hline & & $\mathrm{C} 2$ & $6: 24-28$ & $\begin{array}{l}\text { Mother and daughter and } \\
\text { the head of John }\end{array}$ \\
\hline & & C3 & $6: 29$ & $\begin{array}{l}\text { John's disciples lay his body } \\
\text { in a tomb. }\end{array}$ \\
\hline
\end{tabular}

\section{Part A (Mk 6:14-16)}

Subsequently, I will discuss the parts A, B and C of this bloody story. ${ }^{3}$ Part A starts with the narrator's statement that Jesus' name has become known everywhere and that Herod Antipas heard of him. There are three opinions about Jesus: He is John the Baptist, he is Elijah or he is one of the prophets of old. In all these opinions, Jesus, who has become known everywhere through his miraculous powers, is associated with another figure, with someone from the distant or recent past. The narrator presents Herod's interpretation in direct speech (Mk 6:16): 'John, whom I beheaded, has been raised'. The tetrarch explains Jesus' special powers with the assumption that John has been restored to life in the person of Jesus. That is a somewhat strange form of reincarnation, but whatever the case, it is especially important that Herod makes a connection between Jesus and John. What he hears about Jesus reminds him of John. Jesus himself and Herod nowhere meet in the Gospel of Mark. Herod knows him only from hearing about him, and Jesus warns his followers in 8:15 about 'the yeast of Herod'. This refers to his delusions. In passing, the reader has now also heard that John, who was active at the beginning of Mark and who was arrested shortly after the baptism of Jesus, was executed in the meantime. That brings us to part $\mathrm{B}$.

\section{Part B (Mk 6:17-20)}

The remark in 6:16 about the beheading of John is an introduction to a long flashback, stretching to the end of the story in 6:29. A flashback is a representation within a chronologically ordered story of events that took place in the past but was not narrated at that time. This storytelling technique often occurs in contemporary literature and in movies. Modern people are well acquainted with it. The original readers of Mark may have been surprised because within the whole gospel, this is the only example of a series of events that are not listed in their chronological order.

The flashback offered here includes the events between the arrest of John and his funeral. In Mark 6:16-18, these events are not arranged chronologically, from the past to the narrative present, but from the narrative present to the past. We can show this as follows:
6:16 John has been raised
6:16 Herod has beheaded him
6:17 he is imprisoned
6:18 he criticises the relationship of Herod with Herodias.

The criticism of John is rendered in direct speech. He told Antipas: 'It is not lawful for you to have your brother's wife' (Mk 6:18). This critical remark is the reason for his arrest. John was arrested and imprisoned 'on account of Herodias, his brother Philip's wife, because Herod had married her' (6:17). Moreover, his brother (actually a half-brother) was still alive. That fact is the real problem. In addition, the marriage of Antipas with Herodias contradicts a ban on

3.In my analysis, I am indebted to Delorme (1998:115-129). 
incest in Leviticus 18:16: 'You shall not take your brother's wife' (see also Lv 20:21). Also, according to some texts from the Dead Sea Scrolls, a marriage of an uncle with his niece is regarded as being incestuous (Damascus Document 5:7-11; 11 QTemple Scroll 66:16-17).

The narrator typifies Herod Antipas as a double-minded character. He is wedged between his partner Herodias and John. As a tetrarch, he is the only one who can kill John, but he does not want to do that, while Herodias wants to kill him but she cannot do that (Mk 6:19). In her eyes, Herod is a weakling because he did not put John to death immediately. According to 6:20, Herod fears John and protects him from Herodias, knowing that he is a righteous and holy man, and he likes to listen to what his prisoner has to say, even though John's words are confusing him greatly. The tetrarch listens to John without going to behave differently because of his wise instructions.

\section{Part C (Mk 6:21-29)}

In section $\mathrm{C}$, Herodias gains more control over the course of events. This part takes place in one day: On the birthday of Antipas, which also becomes the day of the death of his prisoner. In this passage, the characters are located at various quarters within the residence of the tetrarch. Antipas whose birthday it is sits in the dining room, together with his courtiers, his officers and the leaders of Galilee. Herodias is in a different room, and John is still in prison. Herodias' daughter walks up and down between the dining room and her mother. A soldier of the guard is sent to the prison from the dining room and he comes back with the head of John.

An intriguing question is of who is actually responsible for the murder of John. More precisely: Which of the three (Herod, Antipas and Salome) is the most guilty, who is less and who is the least guilty? Many (male) exegetes blame the two women, while Herod remains out of range. This view finds little or no support in Mark's story. Herod himself says that he beheaded John (6:16). Without any trial, Herod gives the order for his execution (6:27). Acting rashly, he swears that he will give Salome whatever she wishes, even half of his kingdom. ${ }^{4}$ Here, too, Antipas plays an ambiguous role. Salome's bizarre wish makes him sad. Apparently, he is still standing on John's side, but he wants to keep his promise to the girl and does want to not break his oath in the presence of his guests. However, all that is no reason to speak Herod free. Of the three, he is the most guilty of the death of John.

Herodias is often seen as the evil genius. For quite some time, she considered John as a nuisance, of whom she wanted to get rid of (6:19). Yet, it is not true that she has staged everything that happens at her husband's birthday party. Only when her daughter comes to ask what she will ask of Herod, Herodias sees her chance and answers: 'The head of John the Baptist'. She is a consistent character who strives for the same thing throughout the whole story. She cannot be completely cleared of guilt, but her guilt is less than her husband's guilt, because only he has the power to make come true what Herodias wants. ${ }^{5}$

Finally, the young girl. Was she trying to seduce Herod with her graceful movements and her charms? Many exegetes assume that this is indeed the case. The text, however, only states that she 'pleased' Herod and his guests with her dance (in Greek: $\left.\eta^{\prime} \rho \varepsilon \varepsilon v\right)$. This verb means that her performance appeals to Herod and his messmates, that they are enthusiastic about it and that she pleases her audience with her dance. That she would have performed an exciting erotic dance, with which she would have tried to seduce the spectators, is an idea that more likely has sprung from the fantasy of male exegetes than from Mark's text. ${ }^{6}$

In addition, the dancer is a little girl of around 12 years of age, and not a seductive young woman. ${ }^{7}$

The little girl is going to ask her mother how she should respond to Herod's offer. Apparently, she still sticks to the rule that her mother's will is law. Herodias, in turn, knows very well what she wants: The head of John. The daughter repeats this wish when she stands before Herod again, but she adds a few words (Mk 6:25): 'I want you to give me at once the head of John the Baptist on a platter'. Is her intention that the head of John should be served during the meal on a platter as a kind of dish? By formulating her request in this way, she makes her request immediately ridiculous. However, Herod does not seem to hear this ironic undertone and readily accepts her request. The daughter gets the head of John, but she passes it on to her mother, who is the inventor of this gift.

Salome is not completely innocent, but she is the one of the three who is the least guilty. Her fault is that she only wants what her mother wants, and perhaps even that is not the case, because she distorts what her mother has whispered to her, so that the whole idea becomes completely ridiculous. Not her dance but the oath of Herod causes the fatal outcome of the story. ${ }^{8}$

\section{The function of 6:14-29 within Mark's gospel}

The story about the end of John's life is more than a long digression in Mark's gospel. Why did he include this story in his book? What does it add to his sketch of Jesus' ministry? 5. Regina Janes (2006:449) takes the traditional view that Herodias is the evil genius 'Although Herod affirms his responsibility for John's death, "It is John whom beheaded," the episode lays the blame principally on Herodias, who sought John's death and told her daughter what to ask'. See also Mary Ann Getty-Sullivan (2001:129): 'Mark identifies the real villain as Herodias'.

6. According to Joel Marcus (2000:396), й $\rho \varepsilon \sigma \varepsilon v$ in the Septuagint sometimes has sexual connotations (Gen 19:8; Job 31:10).

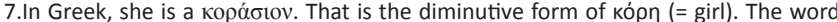
кopó $\sigma 10$ v occurs eight times in the New Testament, where this term applies to two girls: the daughter of Herodias [Mt 14:11; Mk 6:22,28 (two times)] and Jairus' daughter (Mt 9:24,25; Mk 5:41,42), who was 12 years old (Mk 5:42; Lk 8:42).

8.See The Anchor Bible Dictionary, Volume 5, 907: ' $[/] \mathrm{n}$ the Markan account, it is Salome herself who adds the grotesque touch of requesting the head on a platter'. 
To start with, there are connections with what Mark tells us about John in 1:2-15. He lets John himself declare that after him, someone else will come who is more powerful than he is (1:7). His leather belt (1:6) indicates that John (and not Jesus!) follows in the footsteps of Elijah (2 Ki 1:8), who will pave the way for God at the end of time (Mal 3:1, 23-24). As Elijah prepares the way for God, so does John do it for Jesus (1:2-3). They meet only once (1:9). Already in 1:14, John is arrested, and only when he is dead and buried do we hear what happened after his arrest.

In Mark 6:14-29, Jesus only plays an indirect role. The starting point is that all kinds of dubious ideas are circulating about him. Here, we find ideas that also occur in 8:27-28. There are still more connections with the rest of Mark's gospel. John and Jesus are both in favour of the indissolubility of marriage $(6: 18 ; 10: 12)$.

They both collide with political leaders. In John the Baptist, the tension revives that often occurs in Biblical texts between the prophet and the king. This may be the background to the fact that the narrator calls Antipas 'king' in 6:14-29. Jesus also criticises the tetrarch $(8: 15)$, who is the ruler of the area in which Jesus is active in the first part of Mark. His message about God's kingdom includes criticism of the status quo, which is dominated by tyrants. Of them, he says that they oppress their own people and abuse their power (10:42-43).

The story in 6:14-29 functions not only as a flashback but also as a form of foreshadowing to what will happen to Jesus himself later in the gospel. The murder of John already suggests that a second murder will take place, and that is indeed the case in the passion narrative. There are many similarities between 6:14-29 and Chapters 14-16 (Karakolis 2010:134-155). Here are some examples:

- Herodias and the Jewish leaders must wait for a favourable opportunity to carry out their intention to get rid of their enemy $(6: 21 ; 14: 11,48-49)$.

- Both John and Jesus are put in prison and bound (6:17; $14: 46 ; 15: 1)$.

- In both cases, the death sentence is passed by a political figure (Herod or Pilate) who has the power to do so but does not actually want to do it.

- Initially, Herod and Pilate are convinced of the innocence of the prisoner, but under the pressure of others, they suddenly give the order to kill the prisoner.

- The execution is carried out by one or more soldiers (6:27; 15:16-24).

- John's burial is described in almost the same words as Jesus' burial (6:29: 'they laid the corpse in a grave', 15:46: 'he laid him in a grave').

It is tempting to include in this list the fact that they both have been raised up, but in this respect, there is a difference rather than an agreement. It is true that the chosen term is the same ('he has been raised', in Greek: $\eta \gamma \varepsilon \hat{\varepsilon} \rho \theta \eta)$, but in the case of John, it concerns a debatable and dubious opinion of the people and of Antipas, while in the case of Jesus, a positive event is meant that was predicted by himself (14:28) and is repeated by a young man sitting in the open tomb (16:6).

All of this leads me to the conclusion that the story about the murder of John mainly functions as a signal addressed to the readers and points ahead to the future suffering and death of Jesus. The story about Jesus' suffering, death and resurrection is already being prepared here in mirror image.

\section{Intertextuality: Mark and Flavius Josephus}

There are many intertextual relations between Mark's story about the death of John and other texts from Antiquity. ${ }^{9}$ About 20 years after Mark's gospel had taken its current form (around 70 AD), the Jewish historian Flavius Josephus described this same event. He first informs his readers about the divorce and the new marriage of Antipas (Jewish Antiquities XVIII, 5.1 §109-115).

I can summarise this section as follows. Antipas had been married for a long time to a daughter of the Nabataean King Aretas IV when he fell in love with Herodias, the wife of his half-brother Herod. He agreed together with his new love that he would send his Nabataean wife away and that Herodias would then take over her place at the court. The daughter of Aretas got wind of that in time and secretly fled to her father, whom she informed about the nefarious plans of the tetrarch. Aretas did not allow this to happen and started a war against Antipas. In that battle, the whole army of Antipas was destroyed. At this point, Flavius Josephus inserts a flashback (XVIII, 5.2 \$116-119), which reads as follows: ${ }^{10}$

${ }^{116}$ But to some of the Jews it seemed that Herod's army was destroyed by God, indeed very justly taking vengeance, as retribution for John, surnamed the Baptist. ${ }^{117}$ For in fact Herod put him to death, (although he was) a good man and was urging the Jews, practicing virtue and employing righteousness in their affairs toward one another and piety toward God, to join together in baptism. For in this manner, in fact, the baptism appeared acceptable to him, not employing (it) for the dismissal of any sins, but for purification of the body, inasmuch as, in fact, the soul has been cleansed beforehand by righteousness. ${ }^{118}$ And when the others gathered together, for they were aroused to the greatest extent by listening to his words, Herod, alarmed that his abundant persuasiveness to the people might lead to some sedition, for they seemed likely to do everything according to his counsel, regarded it much better, taking action pre-emptively to kill him before something revolutionary would come about from him, than, when an uprising had occurred, not to have regrets after encountering troubles. ${ }^{119}$ And so he [i.e. John], because of Herod's suspicion, having been sent in chains to Machaerus, the fort mentioned above, was there put to death. Now some of the Jews were of the opinion that because of retribution for him [i.e. John] destruction came upon the army, since God wanted to harm Herod.

9.There are also strong intertextual relations between Mark 6:14-29 (where we read about a triangular relationship between Herod Antipas, Herodias and John the Baptist) and the stories about King Ahab, Queen Jezebel and the Prophet Elijah in 1-2 Kings. See especially the data on Jezebel in the following texts: 1 Kings 16:31 18:1-19:2; $21: 1-25 ; 2$ Kings 9:7-10.22.30-37 (Vander Stichele 1999:192-204;
Hoffeditz and Yates 2005:199-221).

10.The following English translation is taken from Rotman 2018:68-83. 


\section{Similarities and differences}

On a number of points, Josephus' story is similar to that of Mark. According to both authors, the death of John the Baptist is an event that had already taken place in the past. They present this incident as a flashback.

Josephus and Mark both are telling that Herodias and Antipas have broken their first marriage in order to enter into a new relationship with each other. Josephus considers Herodias guilty of breaking her marriage to Herod.

In doing so, she 'took it into her head to confound the laws of our country' (Jewish Antiquities XVIII, $5.4 \S 136)$. John's criticism of Herodias' new alliance with Herod Antipas is similar to this: John refers to the laws from Leviticus to condemn this new marriage. Both authors relate that Herod Antipas arrested, imprisoned and killed John. They both mention that John is a person with positive qualities: He succeeded in persuading the people to repent and to start a new life, and Herod Antipas is impressed by his words.

According to Flavius Josephus, some of the Jews believed that the destruction of the army must be a punishment by God because the tetrarch had killed John without an orderly trial (Jewish Antiquities XVIII $5.2 \S$ 116.119). Such popular opinions also play a role in Mark's story. According to Mark, all kinds of opinions were circulating among the people concerning Jesus' identity, such as the idea that Jesus was the resurrected John.

There are also striking differences between the two texts. According to Josephus, Antipas was guided by political considerations to arrest and kill John. He feared that the successful preaching of the Baptist would incite the people to an uprising against his regime. In Mark, the Baptist's criticism of the new marriage of Herodias with her first husband's brother serves as the reason to imprison John. It is surprising that Herodias and Salome in the Jewish Antiquities (XVIII 5.2 \& 116-119) play no role whatsoever and that there is no mention of a dance by Salome during a banquet on her stepfather's birthday. Josephus places the responsibility for the execution of John solely with the tetrarch. In his account, this execution did not take place in Galilee (as in Mark) but in the fortress Machaerus to the east of the Dead Sea.

\section{Conclusions}

This comparison yields the following conclusions. The stories of Mark and Flavius Josephus about the death of the Baptist are quite dissimilar. They are two different views of the common historical core that John was arrested and executed by Antipas. Apart from this hard, historical core, 'the story in Mark 6:17-29 is erroneous in key historical matters [...] and is suffused with legendary and folkloric traits' (Meier 1994:174-175). It is quite conceivable that the story about Salome's performance at her stepfather's birthday party was influenced by gossip among Antipas' subjects about debauched practices at the court of the tetrarch. Flavius Josephus does not mention the two women in his story about
John's execution. This may indicate 'that Herodias and Salome had nothing to do with the execution of John the Baptist' (Lassley Knight 2017:8). All this leads me to conclude that Josephus' story is to be preferred when it comes to the true historical facts surrounding the murder of John.

\section{Intertextuality: Mark, Oscar Wilde and Richard Strauss}

In the final part of this article, I will discuss the way in which characters from Mark 6:14-29 received a new life in the play Salome by Oscar Wilde (1894) and in the libretto of the opera Salome by Richard Strauss (Strauss \& Wilde 1905, 1981; Dutch translation: Wilde 1910; see Fischer 2017; Vander Stichele 2001). ${ }^{11}$

\section{Methodological note}

From Mark to Wilde and Strauss is a great leap. In fact, there are all kinds of intermediate links between Mark and these two modern artists (Bocian 1989:447-450; Merkel 1990). Over the centuries, Mark's story often underwent transformations, starting with Matthew (14:1-12) (Neginsky 2013; Von der Thüsen 1988-1989).

For a long time, artists kept to the available biblical representations, but from the 17th century onwards, we see that artists are dealing with characters from the story of Mark in a very free and independent manner.

According to Jennifer Lassley Knight, in modern Western recreations of the story of Mark, Herodias and Salome are increasingly presented from the literary topos of the 'femme fatale', despite the fact that the responsibility for the execution of John the Baptist primarily lies with Antipas.

Wilde and Strauss build on transformations that are already present in the work of other artists.

Examples of this are the satirical poem Atta Troll by Heinrich Heine (1847), two paintings by Gustave Moreau $(1874,1876)$, the story Hérodias by Gustave Flaubert (1877) and the opera Hérodiade by Jules Massenet (first edition 1881; see Massenet 1884), which is based on Flaubert's novel.

Oscar Wilde turned the short story from Mark into a complete stage play. In its turn, the text of this play has become the basis of a nearly 2-h opera by Strauss. Strictly speaking, we cannot apply the term 'intertextuality' to this network, because this term primarily refers to texts that are interwoven. Here, we come up with the phenomenon that biblical contents are integrated into other art forms, such as a play, an opera and paintings. Material from one art form is often transferred to another art form or from one sign system to another. ${ }^{12}$

11.An excellent study on Wilde's and Strauss's interpretations of Mark 6: 14-29 was written by Wes 1989:19-38. Wes wants to show that by deleting a number of fragments from the text of Wilde's play Strauss gave a more one-sided image of the young Salome as a pleasure object and a sex bomb.

12.In her study on the use of Mark's story in films, Alice Bach (1996:113) points to the tension between the original and the copy. According to her, 'a visual image is in itself a reading, or retelling, not merely an illustration of a reading, but a new text in itself'. 
The term 'intermediality' has come into vogue for this phenomenon. A complete analysis should do justice to this interplay of different art forms.

\section{Characters undergo transformations}

My perspective here is limited to the textual aspects of Wilde's play and of the libretto by Strauss. In Wilde's play, four characters from Mark's story (Herodias, Salome, Herod and John) have been joined by new characters, who play supporting roles and, above all, function as discussion partners for the main characters. ${ }^{13}$

In Wilde's play, the story goes as follows. On his birthday, Herod organises a festive dinner at his residence. During that dinner, he shows an unsavoury interest in the youthful and beautiful Salome, his stepdaughter. She leaves the party room in disgust. Outside, on a spacious terrace, she meets Narraboth, who is silently in love with her. There is also an old well in that area, in which John, who carries the Hebrew name Jochanaan here, is imprisoned. From the cistern, he continues to criticise Herodias loudly because of her illegitimate relationship with Herod. Salome wants to see this ascetic prophet, and Narraboth gets him out of the pit, even though Herod had strictly forbidden to do that. Jochanaan continues to grumble at Herodias and speaks about the coming Saviour. Salome instantly falls in love with Jochanaan, who is still a young man, and she wants to kiss him, but he takes no notice of her advances. Narraboth is so upset by the princess's tender feelings for the prophet that he commits suicide on the spot.

When Jochanaan descends back into the pit, Herod comes out with his retinue. He is looking for Salome, and he finds her sitting next to the dead Narraboth. Herodias wants her husband to kill the raving prophet, but he does not do so, because he knows that John is a holy man. He tries to win over Salome by promising that he will give her a place next to himself on the throne, instead of her mother. He would also like to see the princess performing a dance for him. She agrees to perform only if her stepfather declares under oath that he is willing to give her whatever she wishes. The unsuspecting Antipas swears that he will do that, and then Salome dances the titillating 'dance of the seven veils'. Then, she asks for the head of Jochanaan. Against his will, the tetrarch accepts her request and sends the executioner Naäman to the cistern. The executioner comes back with the cut-off head of Jochanaan on a silver platter. Salome begins to talk to that head, and she kisses it passionately, upon which Herod orders his soldiers to kill the princess. She dies shortly after her beloved one.

Strauss has shortened this long story by deleting a number of lengthy dialogues. In this way, he creates space for the insertion of songs and instrumental music. These forms of expression can sometimes evoke strong emotions from the

13.The cast is expanded by a young Syrian named Narraboth, who is head of the bodyguard; Tigellinus, a young Roman; a Cappadocian, a Nubian; two soldiers; the page of Herodias; five Jews and two Nazarenes; a slave, the executioner Naäman; the slaves of Salome. audience. As a result of these textual changes, Wilde's image of Salome as an inexperienced and fairly innocent young girl is shifting more and more towards a sex-seeking woman.

\section{Continuity and discontinuity}

It is still recognisable that Mark's story is based on Wilde's play and Strauss's opera. At the same time, the ancient story has clearly been 'detached' from the biblical original on a number of points:

- Salome is now playing the leading role. She has grown into an attractive young woman who still has to find her way on the path of love. Men easily fall in love with her, but she pledges her heart only to Jochanaan. Her love for Jochanaan in Wilde's version is innovative in comparison with the description of her role in Mark's story.

- When Jochanaan rejects her, she pursues her own interests. She must and will kiss the head of the prophet, and she manages to do so by claiming his head when she can get everything she wants through Herod's promise under oath. She knows very well what to ask for. She does not have to consult her mother about that, although she makes Herodias happy with her bizarre wish. That she kisses the severed head of Jochanaan might be a shocking form of necrophilia.

- New is not that Salome performs a dance during the party (Mark tells us that as well), but new is that her dance is a sensual dance, performed on the urgent request of her stepfather, who has been undressing her with his eyes from the start of the dinner and regards her purely as an object of sexual pleasure.

Not all these new elements are as original as they seem. For example, kissing the severed head of Jochanaan is also to be found in the poem Atta Troll by Heinrich Heine, but there it is Herodias who kisses his dead lips. It is remarkable that Wilde attributes this deed to Salome. Such a confusion often occurs in intertextual chains. Characters can be mixed together in the course of a long process of recycling old material.

That is also the case with Salome. ${ }^{14}$ We see that in later traditions, she takes over Herodias' behaviours and qualities and thus grows into the person who is most guilty of the murder of Jochanaan, the only man she really fell in love with. That's how she turned into someone she never was, neither in Mark's gospel nor in Josephus' Jewish Antiquities.

\section{Recent performances of the opera Salome (2009 and 2017)}

The performance of the opera Salome under the direction of Peter Konwitschny in 2009 in Amsterdam was positively assessed, but also very negative. He provided the opera with a happy end, which is very different from the final scene of the Salome by Oscar Wilde and Richard Strauss. In the new staging by Konwitschny, John is beheaded, but he comes

14.See Bocian 1989:448: "Um die Gestalten der Herodias und der Salome setzte sich im Mittelalter eine rege Legendenbildung ein, in der die Tochter teils namenlos im Mittelalter eine rege Legendenbildung ein, in der die Tochter teils namenlos
blieb, teils den Namen der Mutter führte und auch mit dieser zu einer Figur verschmolz'. 
back to life later. Is the superstition that Herod Antipas shows in Mark 6:16 to blame for this? Furthermore, now Salome is not killed at the end (as in Wilde and Strauss), so that she can start a new life with Jochanaan. Herod's birthday party has been converted into one large orgy, full of sexual excesses, in the new staging.

The new performance of Salome under the direction of Ivo van Hove in 2017 was reacted to with more enthusiasm. It was a real pleasure to have 'the dance of the seven veils' performed by the soprano Malin Byström (she plays the role of Salome), without taking off her clothes as in a striptease. At the same time, a film was projected in which she performed this dance naked with Jochanaan, with whom she had fallen in love. There was less praise for the final scene, in which the head on a platter was replaced by a huge bowl with a bloody corpse in it. Salome takes a bath in that bowl, a kind of baptism, which marks the beginning of a new life for her. Over the top is also that the corpse crawls out of the dish alive and well.

These two examples show that most intertextual connections with a biblical story as background are deleted and that the old story is loaded with new content. This form of deconstruction also regularly occurs in other re-performances of classical plays, for example, from Greek Antiquity.

\section{Conclusions}

In this article, I have discussed a classical example of a powerful biblical story that can repeatedly be rewritten and reworked into new creations. That may go so far that the new story drifts far from the original. This is certainly the case in the play by Wilde and especially in the Strauss opera. The fact that Herod and Herodias have an illegitimate and incestuous relationship is already present in Mark. Wilde and Strauss transformed Mark's story into a new story, in which the characters are keen on sex and eroticism. In recent performances of Strauss' opera, these aspects are sometimes further blown up, to the absurd.

The images of Salome created by Wilde and Strauss are in line with the predilection for decadence that is characteristic of many works of art during the fin de siècle (i.e. the last decades of the 19th and the beginning of the 20th century). By transforming Salome into a licentious young woman, they want to make the oppressive sexual ethics of their own time ridiculous. In the words of Steven Price (2009-2010:22): 'Salomé may take a biblical story as its ultimate source, but it stands as a complex and beguiling comment upon its own historical time and its author's place within it'.

These transformations may lead later readers to project the sultry role that Wilde and especially Strauss attribute to Salome, and the sexist image of women connected with it, back to Mark's story. In that case, the message of Mark's story threatens to be silenced. However, the special matter about intertextuality as a literary phenomenon is that the opposite is also possible. The old story can continue to raise its voice against interpretations made by later readers, preachers and artists. It remains always possible to reject new interpretations in the light of the original.

\section{Acknowledgements Competing interests}

The author has declared that no competing interests exist.

\section{Author(s) contributions}

W.J.C.W. is the sole author of this article.

\section{Ethical consideration}

This article followed all ethical standards for a research without direct contact with human or animal subjects.

\section{Funding information}

This research received no specific grant from any funding agency in the public, commercial or not-for-profit sectors.

\section{Data availability statement}

Data sharing is not applicable to this article as no new data were created or analysed in this study.

\section{Disclaimer}

The views and opinions expressed in this article are those of the authors and do not necessarily reflect the official policy or position of any affiliated agency of the authors.

\section{References}

Bach, A., 1996, 'Calling the shots. Directing Salomé's dance of death', Semeia 74, 103-125.

Bocian, M., 1989, Lexikon der biblischen Personen, Alfred Kröner Verlag, Stuttgart.

Delorme, J., 1998, 'John the Baptist's head - The word perverted: A reading of a narrative (Mark 6:14-29)', Semeia 81, 115-129.

Fischer, B.D., 2017, Richard Strauss's Salome Opera. Study guide and libretto, Opera Classics Library Series, Opera Journeys Publishing, Boca Raton, FL.

Flaubert, G. 1963, Trois Contes; Un cour simple - La légende de Saint Julien I'Hospitalier - Hérodias, Guilde du Livre, Lausanne, Le Moniteur Universel, Paris.

Freedman, D.N. et al. (eds.), 1992, The Anchor Bible Dictionary, vol. 1-6, Doubleday, New York.

Getty-Sullivan, M.A., 2001, Women in the New Testament, Liturgical Press, Collegeville, MI.

Hainz, J., Schmidl, M. \& Sunckel, J. (eds.), 2004, Personen Lexikon zum Neuen Testament, Patmos, Düsseldorf.

Heine, H., 1847, 1. Auflage, Atta Troll. Ein Sommernachtstraum, Verlag Ludwig Giese, Hamburg.

Hoffeditz, D.M. \& Yates, G.E, 2005 'Femme fatal redux Intertextual connection to the Elijah/Jezebel narratives in Mark 6: 14-29', Bulletin for Biblical Research 15(2), 199-221.

Holy Bible, 1989, New Revised Standard Version with Apocrypha, Oxford University Press, Oxford.

Janes, R., 2006, 'Why the daughter of Herodias must dance (Mark 6.14-29)', Journal for the Study of the New Testament 28(4), 443-467. https://doi.org/10.1177/ $0142064 \times 06065694$

Josephus, 1989, Jewish Antiquities. Books 18-19, transl. L.H. Feldman, Harvard University Press, Cambridge, MA.

Karakolis, C., 2010, 'Narrative Funktion und christologische Bedeutung der markinischen Erzählung vom Tod Johannes des Täufers (Mk 6:14-29)', Novum Testamentum 52(2), 134-155. https://doi.org/10.1163/004810010X12495270769383

Kraemer, R.S., 2006, 'Implicating Herodias and her daughter in the death of John the Baptizer. A (Christian) theological strategy', Journal of Biblical Literature 125(2), 321-349. https://doi.org/10.2307/27638363 
Lassley Knight, J., 2017, 'Herodias, Salomé, and John the Baptist's beheading. A case study of the topos of the heretical woman', International Social Science Review 93(1), Article 1, viewed 18 March 2019, from http://digitalcommons.northgeorgia. edu/issr/vol93/iss1/1.

Marcus, J., 2000, Mark 1-8. A new translation with introduction and commentary, Doubleday, New York.

Massenet, J., 1884, Hérodiade. Opera in four acts, music by J. Massenet to a French libretto by P. Milliet, H. Grémont, and A. Zanardini, Hartmann, Paris.

Meier, J.P., 1994, A marginal Jew. Rethinking the historical Jesus, vol. 2, Mentor message, and miracles, Doubleday, New York.

Merkel, K., 1990, Salome. Ikonographie im Wandel, Lang, Bern.

Metzger, B.M., 1975, A textual commentary on the Greek New Testament, United Bible Societies, London.

Moreau, G., 1874, Salome dancing before Herod, Armand Hammar Museum of Art, Los Angeles, CA.

Moreau, G., ca. 1876, The apparition (Salome), Musée National Gustave Moreau, Paris.

Neginski, R., 2013, Salome. The image of a woman who never was. Nymph, seducer, destroyer, Cambridge Scholars Publishing, Newcastle upon Tyne.

Nestle-Aland, 1963, 25. Auflage, Novum Testamentum Graece, Württembergische Bibelanstalt, Stuttgart.

Nestle-Aland, 1979, 26. neu bearbeitete Auflage, Novum Testamentum Graece, Deutsche Bibelstiftung, Stuttgart.

Price, S., 2009-2010, 'Oscar Wilde's Salome', Royal Opera House, special issue on Salome, 19-22.
Rotman, M., 2018, 'The "others" coming to John the Baptist and the text of Josephus', Journal for the Study of Judaism 49(1), 68-83. https://doi.org/10.1163/15700631 Journal for
12491167

Strauss, R. \& Wilde, O., 1905, Salome. Drama in einem Aufzuge nach Oskar Wilde's gleichnamiger Dichtung, Fürstner, Berlin.

Strauss, R. \& Wilde, O., 1981, Salome, Dover, New York.

Streete, G.P., 2018, The Salome project. Salome and her afterlives, Cascade Books, Eugene, OR.

Vander Stichele, C., 1999, 'Killer queens - The recycling of Jezebel and Herodias as fin de siècle phantasies', in A. Brenner \& J.W. Van Henten (eds.), Recycling biblical figures, pp. 192-204, Brill, Leiden.

Vander Stichele, C., 2001, 'Murderous mother, ditto daughter? Herodias and Salome at the opera', Lectio Difficilior. European Electronic Journal for Feminist Exegesis 2, viewed from http://www.lectio.unibe.ch/01_2/v.htm.

Von der Thüsen, J., 1988-1989, 'Herodias. De receptie van een Bijbels verhaal in de negentiende eeuw', Vooys. Tijdschrift voor Letteren 7(2), 2-14.

Weren, W., 2018, Rode draden in de evangeliën, Halewijn, Antwerpen/Boekencentrum, Utrecht, with online access to 26 PowerPointpresentations, viewed 20 May 2019 from http://halewijn.info/ppt_rodedraden.

Wes, M.A., 1989, 'De sluiers van Salome', Groniek. Historisch Tijdschrift 105(1), 19-38, viewed 12 April 2019, from https://docplayer.nl/64911709-de-sluiers-van-salome. html.

Wilde, O., 1894, Salome. A tragedy in one act, transl. pictured A. Beardsley, Elkin Matthews \& John Lane, London.

Wilde, O., 1910, Salomé. En een Florentijns treurspel, transl. P.C. Boutens, Maatschappij voor Goede en Goedkoope Lectuur, Amsterdam. (Wereldbibliotheek 129). 